\title{
(Nie)dylematy tożsamościowe Polaków w Wielkiej Brytanii na przykładzie badań w hrabstwie Hertfordshire
}

Większość migrantów z Polski, którzy przebywają w Wielkiej Brytanii, długotrwałych, relatywnie dobrze wykształconych, młodych i posiadających przykre doświadczenia w kraju wysyłającym, radzi sobie w nowych okolicznościach społecznych i zawodowych całkiem dobrze. Co więcej, migranci wyrażają zadowolenie z powodu podjęcia decyzji o wyjeździe. To zupełnie nowa jakość w polskiej migracji. Z tego punktu widzenia, problematyka współczesnych migracji jest ważna i trudna do uchwycenia z powodu swojej odrębności w komparacjach do tradycyjnych form migracji. Kiedy ludzie migrują z jednego narodu czy kultury do odmiennych, zabierają ze sobą tożsamość. Egzystując w nowej kulturze, ich tożsamość kulturowa podlega zmianom. Zmieniać może się również ich poczucie przynależności. Autor stara się odpowiedzieć na pytanie o to, jak przedstawia się tożsamość Polaków, zwykłych ludzi w nowym społeczno-kulturowym środowisku. Głównym przedmiotem badań jest próba zbadania związku między tożsamością społeczno-kulturową i migracją. W prezentowanej pracy autor stara się odpowiedzieć na pytanie, jak prezentuje się tożsamość Polaków w Wielkiej Brytanii.

Słowa kluczowe: Wielka Brytania, tożsamość, interakcja, komunikacja międzykulturowa

\section{(Non)Identity Dilemmas of Poles in Great Britain. A Case Study of Hertfordshire County}

Most migrants from Poland who live in Great Britain long-term, fairly well-educated, young and with bad experiences in their sending country can manage quite well professionally and socially in the new circumstances and are basically happy with the decision to have left the country of origin. This is a completely new quality in Polish migration, and therefore is important but difficult to grasp because of its distinctness as compared to traditional forms of migration.

\footnotetext{
${ }^{1}$ Kontakt: seweryn.kapinos@hotmail.com
} 
When people migrate from one nation or culture to another they carry their identity with them. On settling down in the new culture, their cultural identity is likely to change as well as their sense of belonging. In this paper the author attempts to identify the main characteristics of Polish migrants' identity in their new surroundings. The main subject of the study is the relationship between socio-cultural identity and migration.

Keywords: Great Britain, identity, interaction, intercultural communication

\section{Wprowadzenie}

Prezentowany artykuł wpisuje się w szeroki nurt zainteresowań zjawiskiem współczesnych migracji zewnętrznych Polaków i dotyczy wyjazdów do Wielkiej Brytanii po 1989 r., choć wyraźnie należy skonstatować, że rok 2004 z punktu widzenia podejmowanej problematyki stanowi bardziej istotny punkt odniesienia. Ciekawość autora skierowana została na osobliwość sytuacji migracyjnej, która polega na niejednoznaczności, w jakiej znajduje się uczestnik aktu wędrówki. Migrant, opuszczając miejsce pochodzenia, przestaje być - przynajmniej potencjalnie - wyraźnie przyporządkowany do społeczności lokalnej, grupy etnicznej, narodu czy państwa, wyznaczonych przez granice geograficzne, społeczne i kulturowe. Taka sytuacja, której specyfikę szczególnie trafnie oddaje określenie „tu i tam”, czy też znajdowanie się na pograniczu, oznacza pewnego rodzaju zawieszenie między krajem pochodzenia a krajem docelowym i niezależnie od tego, czy tłem dla niej będzie migracja wahadłowa, cyrkulacyjna czy też stała, generuje w mniejszym lub większym stopniu pytania o pochodzenie, identyfikację, przynależność, stosunek do kultury kraju wysyłającego i kultury miejsca migracji. Sytuacja migracyjna oznacza więc spotęgowaną aktywność wokół zagadnienia tożsamości, a egzemplifikujące sytuację migranta pytania: „kim jestem?”, „skąd pochodzę?”, „kim chcę być?” lub „kim chcę pozostać?” są o tyle istotne, że mogą decydować o sukcesie migracyjnej strategii lub mogą dezorganizować funkcjonowanie w ramach nowego otoczenia.

Banalna w swej wymowie obserwacja, zgodnie z którą emigruje nie tylko jednostka, ale wraz z nią kultura i wartości miejsca pochodzenia, posiada daleko idące konsekwencje i stanowi fundamentalny punkt odniesienia prezentowanego artykułu. Innymi słowy tożsamość migruje wraz z osobą, do której należy. Takie podejście zaczerpnięte z klasycznej polskiej socjologii (Chałasiński 1936; Duda-Dziewierz 1938; Thomas, Znaniecki 1976) zakłada, że emigrant nie jest po prostu jakimś indywiduum, lecz podmiotem będącym nośnikiem dążności i postaw społecznych, wartości i ról (Chałasiński 1936: 3-4) - nie jest osobą znikąd, ale uformowaną w pewnym kręgu kulturowym jednostką, posiadającą mniej lub bardziej sprecyzowany system odniesień i identyfikacji, który pozwala się jej wyodrębnić z ogółu, a zarazem przypisać do pewnej kategorii społecznej i kulturowej poprzez 
emocjonalny stosunek do miejsca urodzenia, znajomość historii, praktykowanie zwyczajów i obyczajów, preferowane wartości czy religijność. Wskutek wyjazdu zestaw posiadanych przez jednostkę form autoidentyfikacji i odniesień w naturalny sposób zostaje poszerzony o nowe elementy, które są efektem zmiany miejsca zamieszkania i kontaktu z kulturą odmienną. Sytuacja migracyjna zmusza więc do twórczego i aktywnego poszukiwania odpowiedzi na pytanie „kim jestem?”, a w związku z tym, że „myśl o "posiadaniu tożsamości» nie przychodzi ludziom do głowy tak długo, póki gdzieś przynależą, póki nie mają alternatywy" (Bauman 2006: 14), wyjazd zagraniczny tworzy pewnego rodzaju koniunkturalne zapotrzebowanie na tożsamość i pozbawia ją latentnej, a więc uśpionej natury.

\section{Metodologia badań}

Prezentowany artykuł został oparty na wynikach autorskich badań przeprowadzonych w 2015 r. w Wielkiej Brytanii, które stały się podstawą do pozytywnie zaopiniowanej pracy doktorskiej. Centralny punkt prezentowanego artykułu stanowią badania empiryczne, przeprowadzone wśród Polaków zamieszkujących hrabstwo Hertfordshire ${ }^{2}$ i dotyczące stanu ich tożsamości społeczno-kulturowej ${ }^{3}$. Dla zweryfikowania hipotezy głównej, zgodnie z którą Polaków w Wielkiej Brytanii charakteryzuje tożsamość społeczno-kulturowa oparta przede wszystkim na bazie sentymentalno-tradycyjnej, aktywizującej się bardziej w sferze prywatnej niż publicznej, zrealizowano 237 kwestionariuszy ankiety oraz 21 wywiadów pogłębionych, ustrukturalizowanych, przeprowadzonych $\mathrm{z}$ animatorami kultury, członkami polskich organizacji, nauczycielami i studentami. Autor zwrócił szczególną uwagę na następujące komponenty tożsamości społeczno-kulturowej: zakorzenienie, udział w życiu społeczno-kulturowym, poczucie przynależności, duma i przekonanie

${ }^{2}$ Hrabstwo Hertfordshire położone jest na południu Wielkiej Brytanii i znajduje się w bezpośrednim sąsiedztwie metropolii Londyn. Do największych skupisk Polaków w hrabstwie należą: Hatfield, Stevanage, Watford, Hitchin, Welwyn Garden City.

${ }^{3}$ Dlaczego nie po prostu tożsamość, ale tożsamość społeczno-kulturowa? Świadomy zabieg autora, polegający na użyciu tego złożonego konstruktu zespalającego elementy rzeczywistości społecznej i kulturowej, miał na celu: po pierwsze, odwieść od wrażenia, że przedmiotem badań jest tożsamość indywidualna rozumiana prywatnie, w której najważniejszymi elementami odniesienia miałyby być istotne dla jednostki punkty zwrotne składające się na biografię, ale przeżywane w sposób intymny; po drugie, akcent położony na kohabitację zjawisk społecznych i kulturowych wytycza kompleksowy sposób rozumienia tożsamości, która jest zawsze konstruktem społecznym i kulturowym; rozłączna analiza zjawisk - jak przypomina A. Kłoskowska (1983: 45-46) - mogłaby prowadzić do wyodrębnienia wąskiej kategorii faktów o mało znaczącym dla życia charakterze. Przez tożsamość społeczno-kulturową autor rozumie efekt relacji między zespołem identyfikacji, zaszeregowań, cenionych wartości i sposobu działania nabytego w trakcie socjalizacji i wzajemnego komunikowania z członkami własnej grupy a relatywnie odmiennymi elementami kultury obcej, z jakimi jednostka styka się w trakcie swojego życia (w tym przypadku wywołanymi sytuacją migracyjną). 
o własnej odmienności, praktykowanie zwyczajów typowo polskich, zaangażowanie w życie organizacyjne, religijność.

Właściwy dobór próby, a więc procedury wyboru jednostek obserwacji, należy do kluczowych czynności decydujących o rzetelności wyników badania i rządzi się odpowiednią logiką oraz podlega metodologicznym rygorom (Frankfort-Nachmias, Nachmias 2001: 192-208; Sztumski 1995: 103-111). Probabilistyczny dobór próby, który jest podstawową metodą dobierania dużych reprezentatywnych prób do badań społecznych, w tym przypadku z naturalnych przyczyn był metodą niemożliwą do zrealizowania. Procedura polegająca na zapewnieniu pełnej reprezentatywności była nie do spełnienia z przyczyn związanych z charakterem populacji oraz ograniczonymi możliwościami pozwalającymi dotrzeć do respondentów (brak obowiązku meldunkowego, częste zmiany miejsca zamieszkania, nielegalne zatrudnienie). Przeszkodą w przeprowadzeniu reprezentatywnych badań dotyczących migracji zewnętrznych był również brak wystarczających danych, które mogłyby pozwolić na stworzenie właściwego operatu losowania. Badacz nie był w stanie określić rozmiaru badanej populacji, co wynikało z permanentnej mobilności migrantów oraz z braku odpowiednich rejestrów statystycznych w kraju przyjmującym.

W zaistniałej sytuacji autor wykorzystał metodę doboru celowego (arbitralnego), bazującą na wiedzy o badanej populacji oraz o celach badań (Babbie 2009: 212). Metoda ta charakteryzuje się subiektywnością w selekcji respondentów (Frankfort-Nachmias, Nachmias 2001: 199). Pamiętając o tym, że zastosowanie nieprobabilistycznej metody techniki doboru próby jest możliwe przy posiadaniu szczegółowych informacji o strukturze i zróżnicowaniu zbiorowości będącej przedmiotem badań (Babiński 2004: 159), autor badań dobrał respondentów ze względu na posiadanie określonych cech, o których istnieniu miał świadomość i które były przez niego wstępnie rozpoznane. Akceptując zalecenia stawiane przez E. Jaźwińską (2000), a polegające na konieczności posiadania wiedzy na temat zbiorowości, wstępnej typologizacji i pominięcia kategorii osób, które ze względu na brak pewnych cech nie są reprezentatywne dla populacji, autor na podstawie praktycznej wiedzy wynikającej z kilkuletniego pobytu w miejscu przeprowadzenia badań oraz obserwacji cech osób tworzących zbiorowość dokonał doboru celowego z populacji, wziąwszy pod uwagę „zestandaryzowany” konglomerat cech wspólnych dla przedstawicieli badanej zbiorowości. Zgodnie z zaleceniami J. Sztumskiego (1995: 104), badacz, wykorzystując posiadaną wiedzę na temat badanej zbiorowości, domniemywał, jakie są typowe składniki społeczno-demograficzne tej zbiorowości, i w ten sposób stworzył swoisty klucz, pozwalający na odzwierciedlenie cech zbiorowości.

Autor badań wybrał metodę opartą na triangulacji. W związku z tym, że sondaż może być zastosowany do szerokiego spektrum problemów, a co więcej, można go plastycznie dostosowywać do interesującego zagadnienia, w pierwszej kolejności przy użyciu kwestionariusza ankiety zostały zebrane informacje na temat 
wybranych obszarów aktywności migrantów. Autor wykorzystał ponadto technikę wywiadu częściowo ustrukturalizowanego, związanego ze strategią jakościową. Informacje zebrane za pomocą kwestionariuszy ankiety zostały więc poszerzone o treści uzyskane za pomocą wywiadów ustrukturalizowanych. Zastosowanie takiego zabiegu pozwoliło na pełniejszy opis badanego zjawiska i umożliwiło kontrolę wyników uzyskanych dzięki wykorzystaniu jednej z metod przez dane otrzymane poprzez zastosowanie drugiej. Wybór jakościowego podejścia w kontekście prowadzonych badań był uzasadniony ze względu na skomplikowaną problematykę dotyczącą tożsamości, zwłaszcza w kontekście temporalnym i komparatystycznym. Co więcej, podejście jakościowe pozwoliło wniknąć w płaszczyznę zmian wywołanych aktem migracji w skali indywidualnej biografii, a zarazem odnaleźć rozbieżności w ocenie indywidualnych zaszeregowań i identyfikacji dla kraju pochodzenia i aktualnego kraju przebywania. Stosowność jakościowego podejścia miało pozwolić wniknąć $\mathrm{w}$ subtelną, a zarazem subiektywną sferę prywatnych odczuć, ocen i uwag migrantów.

\section{Polacy w Hertfordshire - cechy społeczne i demograficzne}

Domeną osób objętych badaniami okazała się młodość. Wyraźnie zarysował się obraz młodej emigracji w sensie demograficznym. Badaniami zostali objęci przede wszystkim młodzi migranci pierwszego pokolenia znajdujący się w okresie wysokiej aktywności życiowej i zawodowej. Średnia wieku migrantów wyniosła 34 lata (najstarsza osoba objęta badaniami miała 54 lata, a najmłodsza 17 lat). Znaczna część migrantów z Polski przybyła do Wielkiej Brytanii tuż po otwarciu granic dla nowych członków Unii Europejskiej, a dziś ma trzydzieści kilka lat, co oznacza, że badani, decydując się na wyjazd, w większości byli osobami bardzo młodymi. Wypada przypuszczać, że opuszczali Polskę tuż po ukończeniu edukacji, nie posiadali dużego doświadczenia zawodowego na rodzimym rynku pracy lub nie pracowali w Polsce nigdy, cechował ich stan wolny i nie założyli jeszcze rodzin.

Rozkład badanych ze względu na inną cechę demograficzną - płeć - nie wykazał znaczących dysproporcji. Przebadana została prawie taka sama liczba kobiet co mężczyzn, co może dowodzić, że migracje nie stanowią już jedynie męskiej domeny. Nowa jakość poakcesyjnych migracji dowodzi, że maskulinizacja migracji w coraz mniejszy sposób kształtuje obraz współczesnych wyjazdów zagranicznych i wyraźnie dostrzec można transpozycje w strukturze migrujących mas. Postępująca feminizacja migracji (Castles, Miller 2011) oznacza, że udział kobiet w międzynarodowych strumieniach migracyjnych jest coraz większy.

Wykształcenie należy do czynników silnie selekcjonujących migrujące osoby. Poakcesyjną falę migracyjną charakteryzuje wysoki wskaźnik relatywnie dobrze wykształconych osób (Grabowska-Lusińska, Okólski 2009) - to jeden z najbardziej 
wyrazistych elementów współczesnych wyjazdów zagranicznych. Analiza cech społeczno-demograficznych migrantów w hrabstwie Hertfordshire potwierdza przytoczoną tezę, a nawet ją wyjaskrawia. Osoby objęte badaniami charakteryzowały się wysokim poziomem wykształcenia. Najliczniejszą grupę wśród badanych stanowiły, co ciekawe, osoby z wykształceniem wyższym - 38,14\%, co wskazuje, że w strumieniu migracyjnym, który skierował się do Wielkiej Brytanii, nastąpiła pozytywna selekcja ze względu na wykształcenie. Co czwarta osoba, która wzięła udział w badaniach, legitymowała się wykształceniem średnim (27,97\%). Prawie taka sama liczba osób $(26,69 \%)$ posiadała wykształcenie zasadnicze zawodowe, a pełny obraz badanej zbiorowości dopełniły osoby z wykształceniem policealnym $(5,93 \%)$ i symboliczna obecność osób z wykształceniem najniższym, tj. podstawowym $(1,27 \%)$. Można zatem skonstatować, że polscy migranci przebywający w Wielkiej Brytanii są nie tylko młodzi, ale również dobrze wykształceni.

$\mathrm{W}$ związku z wydłużającym się okresem przebywania poza granicami kraju młodzi stają się starsi i, przebywając poza granicami kraju, dojrzewają do decyzji o założeniu rodziny. Przyjaźnie prowadzona przez brytyjski rząd polityka rodzinna, a także wyrażana przez migrantów zadowalająca ocena pobytu za granicą oraz możliwość łączenia rodzin sprzyjają zjawisku familizacji migracji. Pamiętając o tym, że średnia wieku migrantów wyniosła 34 lata, należało się spodziewać, że znaczna część badanych będzie znajdowała się w związku małżeńskim. Wyniki badań potwierdziły te oczekiwania: prawie połowa migrantów (47,66\%) znajdowała się w formalnym związku (żonaty / zamężna). Prawie tyle samo osób (43,83\%) było w stanie wolnym (kawaler / panna).

\section{Poczucie zakorzenienia}

Zdecydowana większość migrantów w momencie przeprowadzenia badań przebywała poza Polską w sumie nie dłużej niż 10 lat (83,55\%), co oznacza, że data 1 maja 2004 r. stanowiła istotny cenzus w ich migracyjnych biografiach. Otwarcie granic Unii Europejskiej i urzeczywistnienie traktatowego zapisu o swobodzie przepływu osób i siły roboczej otworzyło przed nimi nieskrępowaną możliwość decydowania o miejscu zamieszkania i - ogólnie - życia. Pogłębiona analiza czasu pobytu poza granicami kraju wskazała, że co drugą osobę objętą badaniami (56,97\%) można określić jako migranta wczesnoakcesyjnego, co umownie oznacza, że osoba przyporządkowana do tej kategorii wyjechała poza granice kraju pochodzenia między 2004 a 2012 r. Migranci późnoakcesyjni, a więc ci, którzy przebywali poza granicami kraju wysyłającego nie dłużej niż 2 lata, stanowili 26,58\% wszystkich badanych.

Migranci przedakcesyjni, a więc przebywający za granicą dłużej niż 10 lat, stanowili 16,03\% badanych. Co szósty badany decyzję o wyjeździe za granicę podjął 
więc po 1989 r., ale przed akcesją Polski do Unii Europejskiej. Należy przypuszczać, że w związku z mało liberalną polityką imigracyjną Wielkiej Brytanii przed 2004 r. badani należący do tej grupy byli uczestnikami migracji o charakterze przede wszystkim nielegalnym. Dopiero akcesja Polski do Unii Europejskiej pozwoliła im usankcjonować ich pobyt za granicą, choć trudno w tym przypadku jednoznacznie określić, czy ich obecność poza krajem pochodzenia miała jednoznaczny związek $\mathrm{z}$ pobytem tylko $\mathrm{w}$ Wielkiej Brytanii.

Ocena poziomu zadowolenia z pobytu w Wielkiej Brytanii ma charakter subiektywny. Założono, że składają się na nią wszystkie aspekty wpływające na ogólną jakość życia. Pamiętając o tym, że zdecydowana większość współczesnych migracji ma charakter dobrowolny, a migrantów w hrabstwie Hertfordshire charakteryzowało spore doświadczenie migracyjne, stosunkowo łatwo było przewidzieć, że migranci będą wyrażać pozytywne oceny pobytu za granicą. Analiza danych wykazała, że trzech na czterech migrantów $(77,21 \%)$ zamieszkujących w hrabstwie Hertfordshire było w różnym stopniu zadowolonych $\mathrm{z}$ tego faktu, przy czym stopień zadowolenia (bardzo zadowolony(a), zadowolony(a), raczej zadowolony(a)) rozłożył się wśród badanych w proporcjonalny sposób i wyniósł odpowiednio: $22,78 \%, 28,27 \%$ oraz $26,16 \%$. Biorąc pod uwagę, że $13,50 \%$ badanych nie było w stanie określić oceny swojego pobytu za granicą, można stwierdzić, że tylko co dziesiąta osoba $(9,25 \%)$ była w różnym stopniu niezadowolona z migracyjnej sytuacji. Jednocześnie zbadano zależność między łączną długością pobytu poza granicami Polski a poziomem zadowolenia z przebywania za granicą. Analiza korelacji rho-Spearmana wykazała, że na poziomie istotnym statystycznie ( $\mathrm{p}>0,05)$ występuje związek $(\mathrm{r}=-0,15)$ między łączną długością pobytu poza Polską a oceną pobytu w Wielkiej Brytanii. Analiza korelacji wykazała, że im dłużej badane osoby przebywają poza granicami kraju, tym lepiej oceniają swój pobyt w Wielkiej Brytanii. Pozytywnie w tym kontekście należy zweryfikować tezę mówiącą o związku między długością pobytu a zadowoleniem z pobytu za granicą. Innymi słowy, długość pobytu w Wielkiej Brytanii przekłada się ocenę zadowolenia $\mathrm{z}$ tego pobytu.

Synonimem atrakcyjności Wielkiej Brytanii, a zwłaszcza brytyjskiego rynku pracy dla Polaków, którzy przybyli po 2004 r., jest artykułowana przez nich „normalność" (Galasińska, Kozłowska 2009; Drinkwater, Garapich 2013). Dyskurs „normalności”, rozumianej również jako możliwość godnego życia, przewijał się w wypowiedziach badanych. „Normalność” oznaczała dla migrantów życie w warunkach zgodnych z przyjętą normą, wolnych od zakłóceń i pozbawionych przeszkód, zgodnych z ustalonymi prawami:

Wiem, że żyję. Jest tak, jak być powinno. Powiedziałabym, że normalnie. W Polsce nie czułam się bezpiecznie. Na każdym kroku towarzyszył mi dziwny niepokój, że coś się nie uda, że zabraknie pieniędzy albo że zatrudnia jakiegoś pociotka szefa $i$ stracę prace $(\ldots)(\mathrm{W} / 03)$. 
W Anglii jest całkiem inna rzeczywistość, żeby nie powiedzieć, że jest po prostu normalnie. Tak, jak tu, powinno być w Polsce. Wtedy ludzie nie uciekaliby z kraju. I nawet nie chodzi, że uciekają do Anglii, ale chodzi o to, że w Polsce jest coś takiego nienormalnego, to coś, co nie pozwala ci normalnie żyć, bo albo prywaciarz płaci ci jak niewolnikowi, albo nie daje ci umowy (...). Zawsze może na rachunki nie starczyć. Tutaj nie ma czegoś takiego (W/04).

(...) Politycy powinni tutaj przyjechać i zobaczyć, jak się normalnie żyje (W/05).

Wyrażana przez migrantów „normalność” wiązana była przede wszystkim z finansową sferą życia oraz wykonywaną pracą. Artykułowane zadowolenie z pobytu w Wielkiej Brytanii należało wiązać z jednoczesnym zadowoleniem z sytuacji materialnej, przy czym przez sytuację materialną należy rozumieć, najogólniej rzecz biorąc, sytuację finansową oraz zasobność majątkową, czyli zasoby finansowe, stan posiadania przedmiotów trwałego użytkowania oraz gotowość lub zdolność na nabycia kolejnych środków trwałych i innych przedmiotów oraz aktualnie wykonywaną pracę. Uzyskane wyniki badań wskazały, że ocena zadowolenia z pobytu w Wielkiej Brytanii korespondowała z zadowoleniem z sytuacji materialnej oraz wykonywanej pracy. Analiza korelacji między oceną pobytu w Wielkiej Brytanii badanych osób a ich poziomem zadowolenia ze swojej obecnej pracy i aktualnej sytuacji materialnej wykazała, że im lepiej badane osoby oceniały swój pobyt w Wielkiej Brytanii, tym bardziej były zadowolone ze swojej obecnej pracy oraz ze swojej aktualnej sytuacji materialnej. Co więcej, satysfakcjonująca ocena pobytu w Wielkiej Brytanii oraz opis sytuacji materialnej migrantów w kategoriach jednoznacznie pozytywnych w naturalny sposób łączyły się zadowoleniem z wykonywanej pracy.

Strategia migracyjna stanowi integralną część procesu migracji. W zasadzie można założyć, że w każdy akt migracji wpisana jest pewna intencja uczestnika migracji, która zakłada zamiar, plan, czy też koncept, dotyczący charakteru migracji, w tym czasu jej trwania. Wystarczy w tym kontekście przywołać klasyczne prawo migracji, mówiące, że elementem składowym sieci powiązań między krajem wysyłającym i docelowym krajem migracji są migracje powrotne (Ravenstein 1885). Nie znaczy to oczywiście, że każdy akt migracji musi wiązać się z decyzją o reemigracji, jak również nie musi to oznaczać, że deklarowana chęć wyjazdu na z góry zakładany okres nie może przerodzić się w emigrację osiedleńczą. Autor badań sprawdził, na ile intencjonalna nieprzewidywalność, jako strategia dotycząca przyszłości, charakteryzowała badaną grupę Polaków W tym celu migrantom zadano pytanie: „Jakie są Pana(i) plany na przyszłość, jak długo planuje Pan(i) pozostać w Wielkiej Brytanii?"4. Atrakcyjna dla badacza mobilności intencjonalna nieprzewidywalność

\footnotetext{
${ }^{4}$ Autor założył, że pytanie jest w rzeczywistości sondowaniem na temat planów dotyczących powrotu do Polski, a więc reemigracji. Badane osoby nie miały możliwości wskazania konkretnej, czy też nawet przybliżonej daty powrotu, co wynikało z założonej przez autora badań trudności w określeniu przez migrantów konkretnej kalkulacji dotyczącej przyszłości.
} 
zachowań osób będących uczestnikami migracji zewnętrznych okazała się w kontekście prezentowanych badań strategią równie popularną, co w innych badaniach poakcesyjnych migracji do Wielkiej Brytanii (Eade, Drinkwater, Garapich 2006; Grabowska-Lusińska, Okólski 2009; Frelak, Roguska 2008; Milewski, Ruszczak-Żbikowska 2008; Okólski 2009; Slany, Ślusarczyk 2010; Drinkwater, Garapich 2013). Bardziej jednak uderzającym faktem okazała się deklarowana przez znaczną część badanych chęć pozostania poza granicami kraju na stałe, co potwierdzałoby tezę o charakteryzującej migrantów w Hertfordshire zasiedziałości. Emigrację osiedleńczą zadeklarowało aż 31,82\% migrantów, co oznacza, że jeżeli ich plany dotyczące pozostania w Wielkiej Brytanii się urzeczywistnią, do Polski nie wróci co trzeci spośród badanych migrantów. Pamiętając o tym, że w kontekście skali migracji w ostatnich latach jednym z najważniejszych pytań, które wymaga odpowiedzi, jest pytanie o to, jaka część wyjeżdżających zdecyduje się na powrót do kraju, a jaka część osiądzie na stałe, można stwierdzić, że uzyskane wyniki badań wskazują na trwałość migracyjnych wyborów i z punktu widzenia kraju wysyłającego nie prezentują się optymistycznie.

Emblematyczna jest wypowiedź jednego z badanych: „Wolałbym żyć w Polsce" (W/04). Przed powrotem do Polski migrantów powstrzymuje jednak przede wszystkim przypisywana życiu w Wielkiej Brytanii możliwość osiągnięcia wyższego statusu materialnego, satysfakcjonującej pracy i ogólnego poczucia zadowolenia z życia. Polacy w hrabstwie Hertfordshire okazali się bardziej trwali w swoich wyborach i w mniejszym stopniu przewidywali rychły powrót do Polski niż migranci w Wielkiej Brytanii badani chociażby przez Justynę Frelak i Beatę Roguską (2008) czy Krystynę Slany i Magdalenę Ślusarczyk (2010). Należy podkreślić, że w tym wypadku mamy do czynienia z praktykami jakże innymi od tych charakterystycznych dla okresu przedakcesyjnego - migranci w hrabstwie Hertfordshire nie przypominają już osób przywiązanych ze wszech miar do kraju pochodzenia. Zebrany materiał pozwala stwierdzić, że współcześni migranci przywiązani są raczej do "normalnego" życia, jakiego w ich odczuciu kraj pochodzenia im nie gwarantuje. Nie sposób opisać ich jako „ludzi na huśtawce”, bliżej im do kategorii „ludzi w ruchu”, a więc dążących do znalezienia nowego, lepszego miejsca "na tym świecie” (Okólski 2001: 11), choć wyraźnie należy zaznaczyć, że „ruch” - jak wynika z badań - w kontekście zadowolenia z pobytu w Wielkiej Brytanii i deklaracji trwałości migracyjnych decyzji traci jednak na znaczeniu.

Co w takim razie decyduje o tym, że Wielka Brytania stanowi popularną wśród migrantów destynację migracyjną i jest interesującym miejscem w perspektywie długiego trwania? Do przewidzenia było to, że czynniki ekonomiczne będą odgrywały największą rolę: $34,60 \%$ badanych odpowiedziało, że posiada dobre zarobki, $18,14 \%$ posiadało satysfakcjonującą pracę, a prawie co trzeci badany $(31,65 \%)$ ocenił pobyt w Wielkiej Brytanii w kategoriach szans i perspektyw na wielokrotnie w trakcie badań podkreślane, godne i „normalne” życie („Widzę tu duże szanse na przyszłość). 
Badani podkreślili również rolę kapitału społecznego rozumianego jako system powiązań występujących między członkami grupy, na który składają się kontakty rodzinne i towarzyskie oraz zobowiązania wynikające $\mathrm{z}$ tych relacji. Z tego punktu widzenia pozytywnie zweryfikować należy tezę mówiącą o tym, że rodzina i przyjaciele są silnym czynnikiem zakorzenienia w Wielkiej Brytanii. Blisko co czwarty badany $(23,21 \%)$ miał w Wielkiej Brytanii przyjaciół i znajomych; $11,39 \%$ migrantów miało za granicą chłopaka lub dziewczynę, a więc znajdowało się w bliskich relacjach z inną osobą; 8,44\% przyznało, że w Wielkiej Brytanii mieszkają ich rodzina i krewni. Dodatkowo należy wspomnieć, że 8,86\% migrantów posiadało mieszkanie bądź dom lub też planowało jego zakup i tyle samo $(8,86 \%)$ posyłało swoje dzieci do brytyjskich szkół.

Większość migrantów zaliczała się do grupy osób zadowolonych z pobytu w Wielkiej Brytanii. Badani wyrazili satysfakcję z tego faktu: „tak, jestem zadowolony z pobytu w Wielkiej Brytanii” lub „tak, jestem bardzo zadowolony z pobytu w Wielkiej Brytanii" to najczęściej pojawiające się deklaracje. Polacy byli również zadowoleni ze swojej sytuacji materialnej i wykonywanej pracy. Jest to wyraźny sygnał, który może zapowiadać przedłużanie pobytu poza granicami kraju wysyłającego lub - wprost - migrację osiedleńczą. Z punktu widzenia problematyki badań warto jednak zwrócić uwagę, że poczucie zadowolenia, korzystna praca i czerpana z niej satysfakcja mogą być czynnikami wpływającymi na transformację tożsamości etnicznej i silniej wpływać na identyfikację z nowym krajem, a osłabiać więź z krajem wysyłającym (Mostwin 1985: 35).

\section{Udział w życiu społeczno-kulturowym}

Życie społeczne polskich migrantów to przede wszystkim życie codzienne społeczności etnicznej: świat pracy, krąg przyjaciół, sąsiedztwo, migracyjna siatka tworzona przez rodzinę i bliskich, ale także czas wolny, lokalna polityka, zabawa, uczestnictwo w różnych organizacjach itp. (Mucha 1996). Horyzont aktywności podejmowanych przez migrantów jest szeroki i obejmuje wiele płaszczyzn funkcjonowania w nowym środowisku.

Sytuacja migracyjna jest nową sytuacją społeczną. Migrant opuszcza środowisko, w którym wzrastał i które dobrze znał. Wyjazd za granicę oznacza wyjście poza konstelację rozpoznawalnych, przyswojonych i przewidywalnych elementów układu społeczno-kulturowego kraju pochodzenia na rzecz nowego środowiska. Wyniki prezentowanych badań dały do zrozumienia, że migracja nie oznacza radykalnej zmiany sposobu życia. Silna rola sieci migranckich znalazła przełożenie na najbardziej charakterystyczne cechy funkcjonowania w nowym miejscu. Polacy okazali się zbiorowością endoetniczną, tzn. nakierowaną na własny układ społeczno-kulturowy, czego dowodem są relacje koleżeńskie i sąsiedzkie o wyraźnie 
polskim charakterze. Polacy w hrabstwie Hertfordshire mają „swoich najbliższych w pobliżu". Najbliższe grono koleżeńskie badanych tworzą przede wszystkim rodacy. Przedstawiciele innych grup narodowościowych i etnicznych w zdecydowanie mniejszym stopniu stają się uczestnikami zażyłych relacji z polskimi migrantami.

Jakbym nie mial tutaj rodziny, to na pewno by mnie tu nie było. Raczej w ciemno bym się nie wybrat. Po prostu bym się bat. Rodzina mnie tu ściagnęta (W/14).

„Dlaczego Wielka Brytania? Bo miałem tu brata. Jakby Andrzeja tu nie było, to równie dobrze mógłbym wybrać Francję albo Niemcy (W/04).

Razem z żona staramy się stawiać czoło wszystkim przeciwnościom. Jesteśmy tutaj oboje, więc spokojnie dajemy sobie radę (...). Kiedy coś idzie nie tak, to $w$ naturalny sposób razem rozwiazujemy nasze problemy (W/14).

Gdybym nie byt tu z żona i dzieciakami, to na pewno nie bytoby tu mnie samego (...). Nie wyobrażam sobie, żebym tutaj sam siedział i zarabiał. Będac razem, jest po prostu łatwiej (W/12).

Zaprezentowane wyniki potwierdzają opinię, że kapitał społeczny jest czynnikiem odpowiedzialnym za modelowanie procesu migracji. Sieci powiązań między uczestnikami migracji okazały się bardzo rozpowszechnione i - używając określenia Doroty Osipowicz (2002: 9) - „nasycone dobrem wspólnym”. Co więcej, badania jednoznacznie dowiodły, że wraz z upływem czasu kapitał społeczny, jaki jest udziałem migrantów, nie traci na wartości. Sieć relacji rodzinnych oraz więzi łączące z przyjaciółmi nie tylko okazały się dla badanych cenną pomocą w podjęciu decyzji o wyjeździe i wyborze migracyjnej destynacji, ale również pozwoliły zredukować dyskomfort związany ze zmianą warunków egzystencji i stały się istotnym komponentem funkcjonowania w nowym środowisku nawet w kontekście migracji długookresowej.

Badane osoby w większości przyznały, że do najbliższego kręgu ich przyjaciół w Wielkiej Brytanii należą głównie Polacy - 59,07\%. Samych Polaków wśród najbliższych przyjaciół posiada z kolei $16,46 \%$ migrantów. Oznacza to, że trzech na czterech migrantów $(75,53 \%)$ wśród swoich bliskich przyjaciół ma przede wszystkim Polaków lub tylko Polaków. Wnioski te są o tyle zaskakujące, że większość spośród badanych stanowią osoby zaliczone do grupy migrantów wczesnoakcesyjnych, a więc znajdujących się poza krajem pochodzenia od kilku lat. Trwająca relatywnie długi okres sytuacja migracyjna nie dokonała istotnych przewartościowań w środowisku społecznym migrantów. Polacy w hrabstwie Hertfordshire nie wykazali się skłonnością do budowania związków z osobami innej narodowości pomimo przedłużania się okresu pobytu w Wielkiej Brytanii (Milewski, Ruszczak-Żbikowska 2008: 17). Migranci nadal utrzymywali kontakty przede wszystkim z przedstawicielami własnego kręgu społeczno-kulturowego, co należy uznać za jedną z najbardziej symptomatycznych, a nawet uderzających „przypadłości” na tle badań prowadzonych w innych rejonach Wielkiej Brytanii. 
Agnieszka Bielewska (2013: 6) zwróciła uwagę na podobną cechę Polaków w Manchesterze: pomimo podejmowanych prób nie udało się im zbudować sieci społecznej, która byłaby urozmaicona o osoby niepolskiego pochodzenia. Także badani Polacy w Bradford rzadko wskazywali na bliskość w relacjach z Brytyjczykami (Jaczewska 2014: 167). Podobnie zachowywali się Polacy w Glasgow, dla których najważniejsze okazały się bliskie relacje z konkretnymi środowiskami: rodzinnym i polskim kręgiem przyjaciół (Piętka 2011: 144).

Migranci w hrabstwie Hertfordshire nie ujawnili dychotomii w postrzeganiu polskiej społeczności, jak w przypadku Bradford. „W przeprowadzonych wywiadach z Polakami w Bradford mocno uderza wyraźne rozróżnienie polskiej imigracji przez rozmówców na grupę, z którą się utożsamiają („my”), i na resztę Polaków, z którymi respondenci nie mają i nie chcą mieć zbyt dużo do czynienia („oni”)” pisze J. Fomina (2009: 5). Polacy w Hertfordshire nie dali do zrozumienia, że rywalizują z rodakami o pozycję na rynku pracy lub uznanie ze strony brytyjskiej większości. Badani nie próbowali odejść od kolektywnych form polskości (Rabikowska, Burrell 2009). Brakowało również wyartykułowanego konfliktu między migrantami poakcesyjnymi a przedstawicielami wcześniejszych fal napływu do Wielkiej Brytanii (Garapich 2008).

Wypada zauważyć, że znajomość języka nie powinna być przeszkodą w nawiązywaniu kontaktów z przedstawicielami innych narodów i kultur. Część migrantów już przed wyjazdem dysponowała kapitałem kulturowym, w którego skład wchodziła między innymi znajomość języka kraju przyjmującego, a z drugiej strony relatywnie długi czas przebywania w Wielkiej Brytanii pozwolił z pewnością części migrantów na opanowanie języka angielskiego w stopniu pozwalającym na swobodną komunikację.

Opisując relacje sąsiedzkie Polaków w Hertfordshire, należy skonstatować, że zabrakło wyraźnej otwartości i konfidencjonalności. Zdecydowanie najczęściej występujący typ stosunków z sąsiadami to taki, jaki w skrócie można by nazwać „relacją na dzień dobry”, a więc ograniczającą się do wzajemnego pozdrawiania się, zagadywania, wymieniania kilku słów w trakcie przypadkowych spotkań. W tym kontekście można więc postawić tezę o umacnianiu się stosunków bardziej powierzchownych kosztem relacji bliższych.

Interesująca w kontekście prezentowanej problematyki okazała się podkreślana przez badanych odmienność typu relacji z sąsiadami w kraju pochodzenia i docelowym kraju migracji: „W Polsce sąsiedzi chcą wiedzieć wszystko o tobie i najczęściej wiedzą” (W/17), „Uderza to, że tutaj nie ma zawiści. Każdy sobie rzepkę skrobie. Sąsiad nie zagląda ci przez okno, ma w nosie to, jakim samochodem jeździsz i co kupiłaś w sklepie” (W/11), „Sąsiedzi nie zazdroszczą mi, jakim samochodem jeżdżę, i czy wziąłem na niego kredyt, też ich nie interesuje" (W/14).

Analiza zebranego materiału pozwala stwierdzić, że sąsiedzkość w Wielkiej Brytanii ma generalnie płytki i anonimowy charakter. Kontakty Polaków z sąsiadami 
ograniczone są do konwencji pojmowanej w kategoriach grzecznościowych. Wspólne spędzanie czasu, wzajemna pomoc czy rozwiązywanie lokalnych problemów w zasadzie nie stanowią treści relacji. Tak rozumiana sąsiedzkość nie przypomina sąsiedztwa w tradycyjnym kształcie, opartego na zasadach wspólnotowych i zasadniczo różni się od charakteru relacji z sąsiadami w kraju pochodzenia. Charakter kontaktów z sąsiadami raczej wpisuje je w ogólną tendencję coraz bardziej charakterystyczną dla współczesności, którą rysuje prywatyzacja życia i depersonalizacja kontaktów. Wprawdzie migranci swoje kontakty z sąsiadami oceniają generalnie pozytywnie, ale podkreślają, że są płytkie. Można więc skonkludować: migranci znają dużo osób, ale niewiele o nich wiedzą, i odwrotnie: Brytyjczycy i przedstawicie innych grup etnicznych i narodowościowych niewiele wiedzą o Polakach. W tym kontekście należy stwierdzić, że Polaków w Hertfordshire charakteryzował niski stopień kapitału pomostowego, zakładającego otwartość i wyjście poza własne środowisko, zawiązywanie relacji i więzi nieograniczonych do przedstawicieli własnego kręgu społeczno-kulturowego (Putnam 2000). Taka sytuacja - jak słusznie zauważa badająca wybrane dzielnice Londynu Mariola Janeta (2012: 20) - „z jednej strony sprzyja zachowaniu tożsamości narodowej, z drugiej natomiast - w swej skrajnej postaci - stanowi barierę dla zajścia procesu integracji ze społeczeństwem przyjmującym, który wymaga również międzygrupowych kontaktów”. Łukasz Klimek, który swoimi badaniami objął Polaków mieszkających w nieodległej geograficznie i kulturowo Irlandii, taką taktykę określił jako separacyjną (Klimek 2012: 40-41). Otrzymane przez niego wyniki badań w zakresie deklaracji dotyczących typowego kręgu znajomych oraz grup wsparcia okazały się zbieżne z prezentowanymi danymi empirycznymi. Podobnie jak autor artykułu, Ł. Klimek daleki jest jednak od arbitralnego orzekania o strategii wycofania wśród Polaków. Pomimo powszechności zachowań separacyjnych w wymiarze behawioralnym taka taktyka nie powinna być interpretowana ,jako intencjonalne wycofywanie się z aktywnego udziału i zaangażowania polskich migrantów w życie społeczeństwa irlandzkiego, ale bardziej jako przejaw tego, że wciąż znajdują się oni w początkowej fazie adaptacyjnej" (Klimek 2012: 49) Podobnie trudno jednoznacznie skonstatować, że Polaków w Hertfordshire charakteryzowała wyraźna postawa separacyjna. Znajomość języka angielskiego, praca w międzynarodowym środowisku, posyłanie dzieci do angielskich szkół, deklaracja emigracji permanentnej itd. nie wskazują na rezygnację z możliwości i chęci przyjęcia elementów kultury kraju osiedlenia. Należy jednak przyznać, że strategia relatywnie małej otwartości opóźnia zajście pełnego procesu asymilacyjnego i wskazuje na silny stopień przywiązania do tożsamości uformowanej w kraju wysyłającym.

Jeśli mierzyć spoistość zbiorowości Polaków w hrabstwie Hertfordshire członkostwem w polskich organizacjach, okazuje się, że migranci z Polski nie tworzą trwałej grupy, która świadomie podjęłaby chęć podtrzymywania elementów polskiej kultury oraz manifestowałaby własną odmienność społeczno-kulturową 
(jedynie 20 migrantów - 8,58\% - zadeklarowało przynależność do organizacji; 10 migrantów - 4,30\% - przyznało, że w przeszłości należało do tego typu organizacji, jednak aktualnie nie należy do żadnych organizacji). W rezultacie wydawać by się mogło, że tożsamość Polaków uformowana w kraju pochodzenia skazana jest na znaczne modyfikacje w związku z małym zaangażowaniem w życie publiczne i brakiem chęci pracy dla etnicznej konsolidacji. Tożsamość społeczno-kulturową migranci przechowują i kultywują przede wszystkim w sferze prywatnej i rodzinnej, a w mniejszym stopniu dają jej wyraz w zorganizowanych formach aktywności, które - jak by się mogło wydawać w kontekście bardzo licznej reprezentacji Polaków w Wielkiej Brytanii - powinny być wyraźniejsze.

Podobne spostrzeżenia dotyczą Polaków w Bradford: „Polacy mają stały kontakt $\mathrm{z}$ Polską i nie potrzebują namiastki kraju w formie instytucji polonijnych, nie muszą także odtwarzać bezpowrotnie utraconego świata, jak było to w wypadku Polonii powojennej. Polskość jest dla nich w zasięgu ręki, na każde zawołanie wiedzą, że istnieją polskie sklepy, polska szkoła czy polski kościół, mają dostęp do polskojęzycznych mediów, w każdej chwili mogą wsiąść do samolotu i w tym samym dniu być w Polsce" (Fomina 2009: 28). Na ten aspekt zwrócił również uwagę Thomas Lacroix (2011: 15-17), który, obserwując krajobraz polskich organizacji w Wielkiej Brytanii, dostrzegł relatywnie niski wzrost liczebności organizacji oraz członkostwa, biorąc pod uwagę masowy wzrost liczebności migrantów z Polski. Należałoby się według niego spodziewać rewitalizacji istniejących struktur organizacyjnych oraz pojawienia się nowego typu organizacji w związku z nową sytuacją rynkową i kulturową po roku 2004. Tak się jednak nie stało i jesteśmy raczej obserwatorami niewielkich modyfikacji tradycyjnej mapy organizacyjnej opartej na dwóch filarach: świeckim i religijnym, choć dostrzegalne są pierwsze symptomy zmian, w postaci chociażby Polish City Club - organizacji skupiającej Polaków zajmujących wysokie stanowiska w biznesie. Niechęć wielu nowych imigrantów do angażowania się w sprawy polonijne, w kulturalne i społeczne życie Polonii jest tym, czym można również uzasadnić niezbyt przychylny stosunek „starej” Polonii do emigracji zarobkowej (Garapich 2010).

Autor zauważył, że wiele działań podejmowanych przez badanych, a związanych z promocją Polski czy polskości w aktualnym kraju pobytu odbywa się w sferze życia prywatnego i nie ma żadnego wymiaru instytucjonalnego. Należy zatem postawić tezę, że migrantów charakteryzuje tendencja do wycofywania się do sfery prywatnej - niechętnie działają na rzecz swoich społeczności w sposób oficjalny i zorganizowany. Tendencje te mają swoje bezpośrednie przełożenie na zaobserwowaną bierność w zakresie podejmowania szeregu czynności związanych z realizacją działań zmierzających do promowania wartości typowo polskich wśród samych migrantów, jak również wśród innych grup narodowościowych i etnicznych.

Uzyskane wyniki badań, świadczące o niewielkim zaangażowaniu w aktywność mającą na celu podtrzymywanie polskiej tożsamości w zorganizowanych formach 
aktywności, znalazły komentarz w przeprowadzonych wywiadach z migrantami, którzy podjęli się animacji tego typu działań. Doświadczenia i obserwacje tych osób podpowiadały, że za brak zaangażowania polskich migrantów odpowiada przede wszystkim ucieczka w życie prywatne oraz skupienie uwagi na ekonomicznym aspekcie życia w Wielkiej Brytanii.

W jaki sposób mieliby się zaangażować, jeśli oni tylko o nadgodzinach myśla (...). Ostatnio proponowałem koledze, żeby pomógł nam, to powiedział, że ma dodatkowy kurs, za który mu nieźle płacili, więc powiedział, że może następnym razem. W takiej sytuacji to ręce mi opadają. Czuję, że natrafiamy na pewnego rodzaju mur. Taki wybór między poświęceniem kilku wieczorów na dziatalność charytatywna a przeliczaniem tego na funty albo nawet na złotówki. Szkoda gadać (...) (W/12).

Każdy wyzamykany jest $w$ domu (...). Nieraz było tak, że chodziło nam po głowie, żeby coś zorganizować, ale nie było chętnych (W/14).

Wnioski płynące z badań kierują ku twierdzeniu, że Polacy stoją raczej na uboczu życia społeczno-kulturalnego Wielkiej Brytanii. Defensywne zachowania nie oznaczają jednak strategii obliczonej na kontestowanie elementów układu społeczno-kulturowego kraju migracji. Trudno również orzec o scenariuszu wycofania, zgodnie z którym Polacy mieliby zamknąć się w ramach własnej kultury. Zaobserwowane silne więzy rodzinne i etniczne nie dyskwalifikują polskich migrantów jako aktywnych uczestników życia zróżnicowanej społecznie i kulturowo Wielkiej Brytanii. Bliższe prawdy byłoby raczej stwierdzenie, że stanowią mocno wyróżniającą cechę, która w kontekście trwałości tożsamości społeczno-kulturowej kraju pochodzenia stanowi kapitalny element decydujący o możliwości jej kontynuowania i odporności na przeformułowania.

\section{Etniczny obszar tożsamości Polaków w Hertfordshire}

Analiza etnicznego obszaru tożsamości polskich migrantów w hrabstwie Hertfordshire pokazała, że związek z krajem pochodzenia jest wciąż obecny w życiu badanych. Przywiązanie do społeczności lokalnej (miejsca urodzenia / miejsca pochodzenia) pomimo kilkuletniego pobytu poza granicami Polski jest nadal silne, co w kontekście podkreślanych tendencji kosmopolitycznych (Bauman 2000, 2006; Giddens 2001) jest zjawiskiem interesującym. Migranci przypisują szczególne znaczenie i sens „małym ojczyznom”, które posiadają dla nich wymiar pozamaterialny, świadomościowy i stanowią ważny element odniesienia. Tęsknota i sentyment za miejscem urodzenia i zamieszkiwania przed wyjazdem za granicę wybijały się w tym kontekście w sposób szczególny.

Tożsamość społeczno-kulturowa Polaków w hrabstwie Hertfordshire obfituje w liczne odwołania do kraju pochodzenia. Deklarowane przywiązanie migrantów 
do miejsc i przestrzeni związanych z Polską, a zwłaszcza z konkretnym miejscem urodzenia / pochodzenia, stanowi dowód na istnienie więzi z krajem wysyłającym. Co więcej, pobyt za granicą nie dokonał radykalnych przewartościowań w poczuciu dumy z faktu przynależności narodowej. Dla większości osób objętych badaniem $(60,34 \%)$ przynależność narodowa była powodem do dumy, a więc miała pozytywny wymiar. Co czwarty migrant $(27,85 \%)$ przyznał, że jest bardzo dumny z faktu bycia Polakiem / Polką, natomiast co trzeci $(32,49 \%)$ stwierdzil, że czuje się dumny, jednak z wyraźnym zastrzeżeniem, że nie ma powodów do poczucia wyższości nad przedstawicielami innych narodów. Prawie tyle samo badanych $(24,89 \%)$ przyznało, że są raczej dumni, choć nie ma zbyt wielu powodów do dumy. Tylko co dwudziesty badany $(5,48 \%)$ miał odmienny (negatywny) stosunek do swojej narodowości: I tylko 4,64\% stwierdziło, że nie istnieje wystarczająca ilość powodów, która pozwalałaby czuć się dumnym z faktu bycia Polakiem / Polką, dlatego osoby te raczej nie czuły się dumne; tylko dwóch badanych $(0,84 \%)$ w sposób zdecydowany wyraziło brak związku z posiadaną narodowością. Bycie Polakiem / Polką nie miało znaczenia dla 8,86\% migrantów.

Polscy migranci wyraźnie są świadomi tego, do jakiej grupy etniczno-kulturowej należą i skąd pochodzą. Ich tożsamość Polaków naznaczona jest licznymi odwołaniami do miejsc z przeszłości: domu rodzinnego, szkoły, parafii. Badania dowiodły funkcjonowania dwóch „światów równoległych”: z jednej strony migrantów charakteryzował sentymentalny i emocjonalny stosunek do kraju pochodzenia, a zwłaszcza tego, co wiąże się z miejscem urodzenia i pochodzenia, a więc „ojczyzną prywatną”, a $\mathrm{z}$ drugiej strony cechowało ich podejście czysto pragmatyczne, tzn. podyktowane rachunkiem obliczonym na egzystencję w lepszych warunkach ekonomicznych dających satysfakcję z życia i zadowolenie, jakich nie może zapewnić kraj wysyłający.

„Przestrzeń i miejsce są zasadniczymi składnikami naszego świata” - pisze Yi-Fu Tuan (1987: 13). Miejsce kojarzy się przede wszystkim z bezpieczeństwem, przywiązaniem i tęsknotą. Polscy migranci czuli się w pierwszej kolejności związani z tymi punktami w przestrzeni, które pozwalały im poczuć się swobodnie, przytulnie, bezpiecznie. „Nie ma jak w domu” (W/11) - wyrwana z kontekstu wypowiedź jednego z migrantów oddaje głęboki sens tego fenomenu. W podobny sposób deklarowane przywiązanie do miejsca urodzenia / pochodzenia formułowali pozostali badani:

Marzę, żeby wrócić do Polski, a zwłaszcza do mojej miejscowości (...). Kiedyś tam wrócę, o tym wiem" (W/14).

Czuje się związana przede wszystkim z Gnieznem. Tam się urodziłam i tam się wychowałam. Nawet pomimo tego, że studiowałam w Poznaniu i jestem za granica od więcej niż dziesięciu lat, to czuję się związana przede wszystkim z Gnieznem. Podejrzewam, że jeśli zadałbyś mi to pytanie za dwadzieścia lat, to odpowiedziałabym tak samo. Jak by nie zmieniła się moja historia, to jestem związana $z$ Gnieznem i tam tęsknię (W/03). 
Chciałbym wrócić w moje strony, ale na razie jest niemożliwe (W/02).

Gdyby nie sytuacja w Polsce, to nigdy byśmy nie zdecydowali się na wyjazd (...). Musieliśmy wyjechać (W/13).

Myślę, że kiedyś jeszcze wrócę w swoje strony. Mam nadzieję, że wcześniej niż na starość. Zwłaszcza, że budujemy tam dom (...). Wierzę, że już za kilka lat będziemy u siebie $(\mathrm{W} / 11)$.

Z przytoczonych wypowiedzi przebija tęsknota za miejscem urodzenia / pochodzenia i Polską. Analiza materiałów pozwala stwierdzić, że badanych charakteryzował sentyment do miejsc i przestrzeni sprzed wyjazdu za granicę. W wypowiedziach badanych szczególne miejsce zajmowały bliskie osoby, które pozostały w kraju pochodzenia: „Dziadki nie widują swoich wnuków. To mnie bardzo boli” (W/13), „Nie mogę się doczekać, aby spotkać się ze starymi przyjaciółkami” (W/20), „Kiedy pomyślę Polska, to od razu widzę przed oczami moich rodziców” (W/18). Nie mniejsze znaczenie miały wspomnienia związane z dzieciństwem, młodością, rodzinnymi uroczystościami. Powołując się na Pawła B. Sztabińskiego i Franciszka Sztabińskiego (1997: 260), można byłoby w tym kontekście użyć sformułowania „totalizacja tęsknoty jako stan świadomości”. To deklarowana tęsknota w odniesieniu do trajektorii wyznaczonej przez trzy punkty: miejsce, terytorium, ojczyzna. Migrant, opuszczając dotychczasowe miejsce zamieszkania, tęskni za wszystkim, co polskie, i w tym sensie mniejsze znaczenie ma to, za jakim wymiarem tęskni, istotniejsze $\mathrm{w}$ tym miejscu jest to, że przez sytuację migracyjną tęskni po prostu za tym, co polskie.

Wraz z rozwojem technologii informacyjnej migranci mają wprost nieskrępowany kontakt $\mathrm{z}$ rodziną i bliskimi pozostałymi w Polsce oraz możliwość bycia na bieżąco z najważniejszymi wydarzeniami w kraju wysyłającym. „Internet jako narzędzie komunikacyjne znosi wszelkie ograniczenia terytorialne na dotąd niespotykaną skalę (...). Proces komunikacji, jaki zachodzi w sieci, pozwala migrantom nie tylko na poczucie przynależności do własnego narodu, ale i podtrzymywanie ich tożsamości” (Bierzyńska-Sudoł 2013: 39). Tę szczególną sytuację Monika Metykowa (2010) określa jako „bycie o jedno kliknięcie myszy komputera od domu” znajdującego się w kraju pochodzenia. Nie bez znaczenia jest również fakt, że zdecydowana większość migrujących to osoby młode, dla których Internet jest łatwym w przyswojeniu narzędziem komunikacji i czerpania wiedzy na najróżniejsze tematy, stąd nie może dziwić używane przez M. Bierzyńską-Sudoł (2013) wiele mówiące określenie „e-migracja”.

Utrzymywanie kontaktów z krajem pochodzenia ułatwia również gęsta sieć lotnisk i relatywnie łatwa oraz tania możliwość poruszania się między krajem wysyłającym i przyjmującym (Burrell 2011; Pijet-Migoń 2012). W konsekwencji Polacy w Wielkiej Brytanii mają możliwość częstego odwiedzania rodziny i bliskich w kraju, a ewolucję tę obrazuje stwierdzenie o długotrwałej i męczącej podróży 
autobusem po niskokosztowe loty samolotami (Ignatowicz 2011). Prawie trzy czwarte badanych $(72,88 \%)$ przyznało, że bywa w Polsce przynajmniej dwa razy w roku, dlatego nie może dziwić, że badani posiadali wiedzę na temat aktualnych wydarzeń w Polsce z własnych obserwacji $(35,44 \%)$. Wystarczy przytoczyć kilka wypowiedzi uczestników wywiadu, aby przekonać się o dostępności tanich połączeń lotniczych z Polską:

Do Rzeszowa mam dwa, a czasem nawet trzy połaczenia dziennie. Latanie do Polski nie stanowi żadnego problemu. Można nawet powiedzieć, że łatwiej polecieć do Polski niż wykombinować urlop na ten pobyt (W/14).

Mój kolega co tydzień lata do Polski. Ma ciekawy układ dni w pracy, bo pracuje tylko $w$ piatki, soboty i niedziele. Pracuje niedaleko Cambridge, a stamtad jest blisko na Stansted, więc lotnisko ma pod nosem. Nocuje u znajomych. Takie latanie i tak się mu oplaca (W/12).

(...) teraz już w mniejszym stopniu, ale pamiętam jeszcze nie tak dawno można byto polecieć do Polski za 10 funtów. Ja osobiście na ślub kumpla poleciałem kiedyś za właśnie za 10 funtów i 1 pensa (W/04).

Poza bezpośrednimi wizytami w Polsce badani informacje dotyczące aktualnych wydarzeń w Polsce czerpią również z telewizji $(32,91 \%)$. Wiele osób posiada zestawy do cyfrowego odbioru telewizji satelitarnej, które dają dostęp do dziesiątków kanałów telewizyjnych w języku polskim. Co więcej, również dostęp do Internetu daje możliwość oglądania telewizji. Migranci przyznają, że najczęściej oglądają kanały polskiej telewizji publicznej oraz Polsat, TVN, TVN24 i Puls.

Co trzeci migrant $(32,49 \%)$ informacje dotyczące Polski uzyskiwał w trakcie spotkań towarzyskich, a 14,77\% badanych z radia dowiadywało się o najważniejszych wydarzeniach w kraju pochodzenia (RMF, Radio Zet, PR 1, PR 3, TokFm). Najmniej osób $(11,39 \%)$ z gazet i czasopism czerpało informacje dotyczące Polski (Newsweek, Polityka, Cooltura).

W ostatnich latach systematycznie zwiększa się liczba polskich dzieci w Wielkiej Brytanii. Jest to rezultat działań mających na celu łączenie rodzin, wyższego od przeciętnej dla mieszkańców Wielkiej Brytanii wskaźnika dzietności wśród Polek oraz, na co zwrócili uwagę Paulina Trevena, Derek McGhee oraz Sue Heath (2016: 87), strategii obliczonej na osiągnięcie „lepszego życia” dzięki edukacji. Jednocześnie obserwowalne jest zapotrzebowanie na polskie szkoły (Irek, Małek, Napierała, Praszałowicz, Pustułka, Pyłat, Grzymała-Moszczyńska 2012). W przeprowadzonych wywiadach wielokrotnie przewijał się wątek nauczania polskich przedmiotów, zwłaszcza języka polskiego i historii. Badani wyraźnie dostrzegli potrzebę zorganizowanego systemu nauczania młodych pokoleń, a zarazem wyrazili aprobatę dla już funkcjonującego systemu nauczania w ramach tzw. polskich szkół sobotnich, które, co ciekawe, stanowią największy i najszybciej rozwijający się typ struktury obecnej w krajobrazie stowarzyszeniowym polskich organizacji 
migrantów w Wielkiej Brytanii (Lacroix 2011: 15-17). Uczęszczanie do polskich szkół powinno w opinii badanych ułatwić utrzymanie kontaktu z tym, co ogólnie rzecz ujmując polskie. Wydaje się to szczególnie istotne z punktu widzenia osób, których plany na przyszłość oznaczają migrację osiedleńczą. Same rozmowy z rodzicami oraz ewentualnie kontakt $\mathrm{z}$ rodziną i bliskimi w trakcie odwiedzin Polski wydają się niewystarczające, aby dostarczyć dziecku treści pozwalających na transparentne odwołanie do polskich korzeni. Badani silnie zaakcentowali edukację i wychowanie jako motywy przewodnie działań polskich organizacji działających w hrabstwie Hertfordshire.

Mamy sporo chętnych na naukę w naszej szkole. Dlatego nabór zaczynamy już kilka miesięcy wcześniej. Zresztą chcemy się zawczasu upewnić, jak dużo dzieci będzie posyłane do naszej szkoty (W/20).

Trudno mi sobie wyobrazić, aby moje dziecko nie miało styczności z takimi przedmiotami, jak jezzk polski czy historia. Ja mogę dziecku sporo przekazać wprawdzie, ale nauczyciel zrobi to w lepszy sposób. Trudno byłoby mi uczyć dziecko o Piłsudskim czy o Mickiewiczu (W/01).

Wstyd, jakby moje dziecko nie znało wierszyka «Kto ty jesteś - Polak mały». Szkoła jednak robi swoje. Żałuję, że nie mogę posyłać dziecka do szkoty, która uczyłaby więcej o Polsce. No, ale cóż... Jestem w Anglii. Dlatego posyłam dzieci do polskiej szkoły, gdzie chociaż zajęcia sa od czasu do czasu, to jednak pewne fundamenty zawsze zdobywa (W/16).

Istotną płaszczyzną życia migrantów jest tradycja kraju pochodzenia, którą migrujący najczęściej „zabierają ze sobą”. Na tradycję składają się między innymi obchody różnego rodzaju uroczystości o charakterze osobistym (urodziny, imieniny, rocznice ważnych uroczystości), rodzinnym (rocznice wydarzeń rodzinnych), religijnym (święta religijne, komunie, chrzciny) oraz narodowym (rocznice ważnych z punktu widzenia państwa i narodu wydarzeń). Stanowią one trwały i nieodłączny element kultury etnicznej, a ich kultywowanie nabiera w środowiskach emigracyjnych szczególnego znaczenia. Okazało się, że Polacy za granicą praktykują przede wszystkim święta o religijnym rodowodzie, jednak są one przez migrantów postrzegane w największym stopniu przez pryzmat rodzinny. Migranci zaakcentowali przede wszystkim familijny wymiar ich świętowania. Do podobnych wniosków doszła Ewa Garstka (2015: 145), która w nieodległej geograficznie i kulturowo Irlandii, obserwując kulturę świętowania młodych Polaków, dostrzegła, że osadzenie tożsamości nie opiera się wyłącznie na religii, ale wynika przede wszystkim z kultury oraz środowiska, jakim jednostka nasiąka. W tym sensie trudno potraktować pieczołowicie przygotowywane, a następnie uroczyście konsumowane świąteczne dania jedynie jako element sacrum. Jest to raczej element scalający zabarwiony emocjami, o wybitnie rodzinnym charakterze. Również Polacy w Londynie (Rabikowska 2010) i Manchesterze (Bielewska 2013) święta chcą przeżywać po polsku, 
$\mathrm{z}$ tradycyjnie przygotowanymi potrawami, w rodzinnej atmosferze wraz $\mathrm{z}$ obserwowalnym zwyczajem - spacerem ze święconką do kościoła.

Dla zdecydowanej większości Polaków w Wielkiej Brytanii najważniejsze w czasie świąt Bożego Narodzenia czy Wielkanocy były elementy odwołujące się do życia rodzinnego i tradycji: spędzenie czasu z najbliższymi, wyjątkowa atmosfera tych dni, podtrzymywanie zwyczajów. Opinii w tym zakresie nie różnicowały zmienne społeczno-demograficzne.

To chyba jedyny okres $w$ roku, kiedy wszyscy dajemy na wstrzymanie (...). Siedzimy $w$ rodzinnym gronie, dużo jemy, ogladamy komedie $w$ telewizji, pijemy alkohol (...). Wypada żałować, że tylko raz w roku wypada taki okres (W/14).

Kiedy spędzam święta $w$ Wielkiej Brytanii, to czuję się mimo wszystko jak w Polsce. Zwłaszcza dzięki temu, że jesteśmy tu cała rodzina. Wprawdzie okrojona, ale nasza mała $i$ swojska $(\mathrm{W} / 21)$.

Jestem tutaj sama, ale zawsze zapraszaja mnie znajomi. Zawsze ci sami. Jest bardzo rodzinnie $z$ nimi (W/03).

Migranci zdecydowanie rzadziej podkreślali religijny wymiar świętowania. Uczestniczenie w nabożeństwach, wspomnienie narodzin Jezusa Chrystusa, przeżycie duchowej odnowy - o tych sprawach częściej w porównaniu z innymi mówiły osoby starsze, żonate / zamężne i regularnie praktykujące.

Chce, aby było wychowywane $w$ duchu polskiej religijności, znało i szanowało nasze tradycje, miało odpowiedni kręgostup moralny (A/134).

Żałuje, że zawsze jest problem ze spowiedzia przed świętami, bo ciężko księdza złapać, a nie wiem, w jaki sposób spowiadać się u angielskiego księdza (W/12).

Badani zwrócili również uwagę, że święta dają im poczucie bliskości z tymi, którzy zostali w kraju. Elementy emocjonalne i sentymentalne przewinęły się m.in. w następujących wypowiedziach:

To czas wspomnień mojego domu rodzinnego, czas spędzony z rodzina i bliskimi (A/21).

Czuję więź z tymi, którzy zostali w kraju, czuję się częścia wspólnoty (A/125). Zwyczaje te zostały wpojone mi jako dziecku, niosa one treści religijne i kultywowania rodzinnych spotkań. Niosa ze sobą szczególnie bardzo wyjątkowy czas spędzony z rodzina i bliskimi (A/11).

To czas wspomnień mojego domu rodzinnego, czas spędzony z rodzina i bliskimi (A/21). Wspomnienia $z$ dzieciństwa i rodzinna atmosfera (A/45).

Kojarza się z rodzina, przyjaciótmi, miejscem pochodzenia (A/126).

Łatwiej mi znieść tęsknotę za krajem, czuję się związana z Kościołem i z bliskimi (A/127).

Kojarza się z bliskimi (A/68). 
Migranci dali również do zrozumienia, że zwyczaje traktowane są przez nich w kategoriach przywiązania do Polski, a więc pozwalają na podtrzymywanie tożsamości społeczno-kulturowej uformowanej w kraju macierzystym:

Przypominaja o Polsce (A/135).

Przypominają o Polsce i skąd pochodzę (A/136).

Ludzie, którzy nie mają tradycji i historii, są ludźmi wyjętymi ze świata. Tradycja pozwala nam lepiej zrozumieć własna tożsamość (A/86).

Przypominają, skąd naprawdę pochodzimy, i pozwalaja się poczuć trochę bardziej Polakiem poza granicami kraju (A/48).

Kojarza mi się z Polską (A/34).

Pomagaja zachować świadomość i tożsamość narodową. Przybliżaja nas do Polski (A/28).

Zebrany materiał pozwala stwierdzić, że polskie święta i zwyczaje stanowią trwały i nieodłączny element kultury etnicznej, a ich praktykowanie nabiera w trakcie migracji szczególnego znaczenia i może być rozumiane jako sposób walki z poczuciem obcości i zagubienia oraz formą odtworzenia „polskiego klimatu” (Slany, Ślusarczyk 2010). Zwyczaje typowo polskie nie zostały zepchnięte przez nich na boczny tor, nadal stanowią istotny komponent tożsamości społeczno-kulturowej. Z tego punktu widzenia można przychylić się do tezy, że „polska tradycja zabierana jest przez migrantów do nowego kraju”.

Ilość wskazań na święta i wydarzenia typowo brytyjskie okazała się znacznie mniejsza niż na święta i wydarzenia o polskich korzeniach. Nie musi to wcale oznaczać, że proces asymilacji migrantów do sfery kultury kraju pochodzenia posiada ograniczony charakter, czy też że Polaków charakteryzuje uporczywe trwanie w obrębie własnej kultury. Słowa uczestników wywiadów dowodzą, że migranci, po pierwsze, nie do końca akceptują komercyjny charakter brytyjskich świąt Christmas i Easter. Uważają, że przepełnione są aktywnością związaną z konsumpcją. Po drugie migranci uważali również, że brytyjskim wydarzeniom o charakterze świątecznym brak głębokiego sensu, jaki zdecydowanie posiadają "polskie” święta Bożego Narodzenia i Wielkanocy - głównie chrześcijańskie w swej wymowie i typowo polskie. Polskie święta mają dla migrantów przede wszystkim wymiar magiczny i przede wszystkim familijny.

Agnieszka Bielewska (2013: 5), prowadząc badania wśród Polaków w Manchesterze, dostrzegła, że wprawdzie migranci wiedzą o funkcjonowaniu polskiego kościoła, ale traktują go w sposób ambiwalentny - tylko nieliczni uczestniczą w nabożeństwach regularnie. Migranci najczęściej wskazywali na brak czasu, daleką odległość do kościoła lub wprost brak potrzeby uczestniczenia w mszy świętej. Co więcej, nie angażowali się w życie pozakościelne parafii. Podobną postawę wykazywali Polacy w Bradford. Joanna Fomina (2009: 16) zwróciła uwagę na to, że Polacy dystansowali się od wizerunku gorliwych i bogobojnych. Raczej byli 
niepraktykujący, „mniej praktykujący”, zrażeni do kościoła, niezmuszeni przez otoczenie lub odepchnięci przez konserwatyzm instytucji.

Badania prowadzone $\mathrm{w}$ hrabstwie Hertfordshire doprowadziły do podobnych wniosków - religijność Polaków posiada „względne znaczenie”. Adekwatność używanego w naukowym i codziennym dyskursie zestawienia „Polak - katolik” w kontekście prezentowanych badań jest więc wciąż do pewnego stopnia uzasadniona, choć badani w mniejszy sposób akcentowali chociażby religijny charakter niedzieli i w mniejszym stopniu praktykowali. Największa część migrantów $(28,69 \%)$ przebywających w hrabstwie Hertfordshire uczestniczyła w praktykach religijnych w sposób niesystematyczny, tzn. robiła to prawie co tydzień $(11,81 \%)$ lub mniej więcej raz w miesiącu (16,88\%). Większą grupę stanowili Polacy, którzy zadeklarowali udział w praktykach religijnych rzadziej, bo kilka razy w roku $(27,85 \%)$ - respondenci ci brali udział przede wszystkim w najważniejszych dla chrześcijaństwa wydarzeniach, takich jak Boże Narodzenie i Wielkanoc, oraz incydentalnie, okazjonalnie w trakcie pozostałej części roku liturgicznego. Co dziesiąty badany $(9,70 \%)$ brał udział w praktykach religijnych rzadziej niż jeden raz na rok, a $8,44 \%$ do kościoła nie uczęszczało wcale.

Irena Krotofil wykazała na podstawie przeprowadzonych na Wyspach Brytyjskich badań, że partycypacja w niedzielnych rytuałach podtrzymuje znany z kraju rytm święta i zwykłego dnia. Świadomość, że bliscy mieszkający w Polsce poruszają się w podobnym rytmie, „podtrzymuje więź z rodziną przez zachowanie ciągłości rodzinnych zwyczajów i typowych zachowań” (Krotofil 2013: 174). „Niedziela jak to niedziela, wiadomo, że trzeba odpocząć i pójść w miarę możliwości do kościoła, bo tak jestem nauczona" (W/05) - podkreśliła jedna $z$ badanych, a jej stwierdzenie dobrze uzupełnia wypowiedź innej osoby, która zwróciła uwagę, że „nie ma znaczenia, czy do kościoła pójdzie w Hatfield czy w rodzinnym domu. Jak wyjeżdżamy z mężem do kościoła tutaj, to przypominają się rodzinne strony. Jakoś tak mam, że rozczulam się niedzielami (...)" (W/21).

Badania Marcina Lisaka (2010) wykazały, że polscy katoliccy świeccy w Wielkiej Brytanii oczekują przede wszystkim typowo polskich obrzędów i zwyczajów religijnych, zaś od duchownych oczekują zapewnienia posługi sakramentalnej i praktyk religijnych, które nosiłyby typowo polski rys. Okazało się, że gdyby w bezpośrednim sąsiedztwie znajdowała się polska parafia i polski duszpasterz, zdecydowanie częściej w praktykach religijnych uczestniczyłoby $14,77 \%$ badanych z hrabstwa Hertfordshire, a co czwarta osoba $(24,89 \%)$ zadeklarowała, że raczej częściej chodziłaby do kościoła. Tak więc w przypadku 39,66\% badanych bliskość polskiej parafii i polskiego księdza mogłaby wymiernie zmienić stopień uczestnictwa w praktykach religijnych.

Polacy w Wielkiej Brytanii deklarują chęć wychowywania własnego potomstwa w duchu wiary katolickiej. Chcą, aby ich dzieci wychowywane były w duchu treści i wartości typowo katolickich. Pragną więc zapewne, aby świąteczny 
charakter niedzieli był nadal kontynuowany, zwłaszcza jej familijny, emocjonalny i wspólnotowy wymiar. Scenariusz zetknięcia migrantów z nową rzeczywistością społeczno-kulturową w kontekście ich tożsamości religijnej nie budzi zdecydowanych obaw, że tradycyjna polska religijność zostanie nagle zatracona, choć jednak uległa wyraźnemu osłabieniu.

\section{Podsumowanie}

Prezentowane badania, jakie autor przeprowadził w hrabstwie Hertfordshire, stanowią dowód na to, że kultura i wartości przekraczają ramy środowiska, w jakim zostały uformowane. Migracja stanowi naturalne wyzwanie dla tożsamości, trudno jednak w kontekście uzyskanych wyników badań przychylić się do tezy o postępującym procesie „brytyizacji” Polaków w Wielkiej Brytanii (Paleczny 2008: 102), czy też „ucieczce z polskości”. Migracja nie dokonała radykalnych przekształceń w tożsamości społeczno-kulturowej Polaków mieszkających w hrabstwie Hertfordshire. Słusznie brzmią w tym miejscu słowa Ewy Nowickiej (2010: 206), że należy podważyć koncepcję wszechobecnej i koniecznej deterytorializacji tożsamości współczesnego człowieka. Prezentowane badania wskazują, że Polacy zachowali kluczowe elementy składające się na identyfikacje, zaszeregowania i odniesienia o charakterze typowo polskim, choć emocjonalne i sentymentalne (tradycyjne) ingrediencje odgrywały w tym przypadku kluczową rolę. Nieprawdziwe okazały się obawy, że Polacy, którzy opuszczą kraj, utracą emocjonalny stosunek do tradycji, historii i kultury kraju pochodzenia. Polacy nie roztopili się w ramach nowej struktury i nie utracili swojego specyficznego charakteru.

Można odnieść wrażenie, że dla Polaków w Hertfordshire - podobnie jak dla Polaków, którzy stali się obiektem badań innych autorów na terenie Wielkiej Brytanii - migracja nie jest źródłem stanu dysfunkcjonalnego ani też nie powoduje dylematów tożsamościowych. Migracja nie jest też źródłem frustracji. Autor skłania się raczej ku twierdzeniu, że jeśli nawet migracja może powodować pewien kryzys, to Polacy w Hertfordshire stanowią przykład, w jaki sposób można tę sytuację zmiany (przełomu, problemu) przekuć w sukces. Innymi słowy, o ile sytuacja migracji może powodować kryzys, o tyle raczej w sensie pozytywnym, polegającym, jak to określiła D. Mostwin (1985: 55), na wyzwoleniu dodatkowej energii, staniu się motorem twórczym. Rodzina, sieć powiązań, podtrzymywanie kontaktu z krajem pochodzenia, a więc strategie modelowania i facylitacji (Boski 2009: 510), pozwalają Polakom w Wielkiej Brytanii przełamać ten kryzys. Sytuacja migracji nie rodzi więc poczucia porażki czy rozgoryczenia i tylko w niewielkim stopniu przypomina kulturę migracji charakterystyczną dla lat 90. XX w., kiedy upowszechnił się wzór bycia „tu i tam”, a więc stan zawieszenia między krajem wysyłającym i przyjmującym był nie tylko akceptowalny, ale i powielany. Rację miał 
W. Łukowski, który prognozował, że całkowite otwarcie krajów Unii Europejskiej będzie oznaczało stopniowy kres strategii mobilności biwalentnej. „Im większa wewnętrzna otwartość i spójność systemowa od Bugu po Tybr, tym mniej miejsca dla podziału na «tu» $\mathrm{i}$ «tam», nawet jeśli długo jeszcze zachowane będą różnice w poziomach życia" (Łukowski 2001: 160).

Z prezentowanych badań wyłania się obraz migrantów, którzy nie znajdują się już w wymuszonej sytuacji zawieszenia. Nie ma również konieczności, aby jednoznacznie musieli opowiedzieć się za wiernością układowi społeczno-kulturowemu kraju pochodzenia albo wartościom kraju przyjmującego. Ta dogodna dla migrantów sytuacja wynika z trzech istotnych czynników. Po pierwsze, dobrowolność podjętej decyzji o migracji wyklucza przyjęcie narzuconej przez motywy i okoliczności strategii adaptacyjnej. Migrant świadomie kreuje proces wchodzenia w nowe społeczeństwo i sam decyduje o własnych planach na przyszłość. Po drugie, relatywna bliskość kraju pochodzenia oraz kapitał społeczny w postaci sieci migranckich osłabia możliwą sytuację szoku kulturowego oraz poczucie wyobcowania czy zagubienia (bycie o „jedno kliknięcie myszy” od kraju pochodzenia czy dwugodzinny lot samolotem Ryanair plastycznie obrazują dogodną dla migrantów sytuację). Wreszcie, po trzecie, prowadzona od kilku dziesięcioleci przez kolejne brytyjskie rządy polityka multikulturalizmu oraz otwartość społeczeństwa przyjmującego pozwalają licznym grupom etnicznym na życzliwą koegzystencję i kultywowanie własnej tożsamości. Powyższe uwarunkowania sprawiły, że Polacy w Wielkiej Brytanii znaleźli się w sprzyjających warunkach pozwalających na zachowanie tożsamości społeczno-kulturowej wytworzonej w kraju pochodzenia. Nie są więc zmuszeni ani do uporczywego trwania przy własnej kulturze, ani do poddania się presji na możliwie szybką akulturację.

Uderzające, że polska tożsamość jest celebrowana raczej prywatnie (kameralnie), tzn. w zaciszu własnego domu. Polacy w hrabstwie Hertfordshire nie różnią się pod tym względem od rodaków zamieszkujących inne miejsca w Wielkiej Brytanii. Familijność migracji oraz gęsta sieć kontaktów z przedstawicielami tej samej grupy narodowej sprzyjają takim praktykom. W sytuacjach publicznych podkreślanie typowo polskich charakterystyk było rzadkie, choć przyjazna „filozofia społeczeństwa", która uznaje różnorodność za zjawisko naturalne i cechę społeczeństwa, pozwala na taką manifestację. Tożsamość Polaków w Hertfordshire okazała się również bazować na resentymentach i emocjach, co pozwala pozytywnie zweryfikować założoną tezę o sentymentalno-tradycyjnym podłożu identyfikacji. Artykułowana tęsknota za krajem, nostalgia za przeszłością, pamięć o pozostałych w kraju członkach rodziny i bliskich znajomych, znalazły odzwierciedlenie $\mathrm{w}$ zrealizowanych kwestionariuszach ankiety i przeprowadzonych wywiadach. Z tego punktu widzenia należy wyraźnie podsumować, że Polaków w Hertfordshire charakteryzuje tożsamość społeczno-kulturowa oparta przede wszystkim na bazie sentymentalno-tradycyjnej, która aktywizuje się bardziej w sferze prywatnej niż publicznej. 


\section{Bibliografia}

Andrejuk K (2011), Polish students at London universities and their attitudes towards the Polish diaspora in the UK, „Studia Migracyjne - Przegląd Polonijny”, nr 1, s. 291-308.

Babbie E. (2009), Podstawy badań społecznych, Warszawa: Wydawnictwo Naukowe PWN.

Babiński G. (2004), Metodologia a rzeczywistość społeczna. Dylematy badań etnicznych, Kraków: Zakład Wydawniczy NOMOS.

Bauman Z. (2000), Ponowoczesność jako źródło cierpień, Warszawa: Wydawnictwo Sic!.

Bauman Z. (2006), Płynna nowoczesność, Kraków: Wydawnictwo Literackie.

Bielewska A. (2013), Kupowanie polskości - tożsamość narodowa jako towar wśród polskiej migracji poakcesyjnej w Wielkiej Brytanii, w: Praszałowicz D., Łużniak-Piecha Ł., Kulipńska J., Młoda polska emigracja w UE jako przedmiot badań psychologicznych, socjologicznych i kulturowych, http://www.euroemigranci.pl/dokumenty/pokonferencyjna/Bielewska.pdf [data dostępu: 16.04.2016].

Bierzyńska-Sudoł M. (2013), Proces podtrzymywania tożsamości narodowej współczesnych migrantów polskich w przestrzeni Internetu (na przykładzie Wielkiej Brytanii i Irlandii 2004-2011), Bydgoszcz: Wydawnictwo Uniwersytetu Kazimierza Wielkiego.

Boski P. (2009), Kulturowe ramy zachowań społecznych. Podręcznik psychologii międzykulturowej, Warszawa: Wydawnictwo Naukowe PWN.

Burrell K. (2011), Going Steerage on Ryanair: Cultures of Air Travel for Migration from Poland to the UK, „Journal of Transport Geography”, Vol. 19, Issue 5, s. 1023-1030.

Castles S., Miller M. J. (2011), Migracje we współczesnym świecie, Warszawa: Wydawnictwo Naukowe PWN.

Chałasiński J. (1936), Emigracja jako zjawisko społeczne, „Przegląd Socjologiczny”, z. 3-4, s. 491-518.

Drinkwater S., Garapich M. P., Migration Plans and Strategies of Recent Polish Migrants to England and Wales: Do They Have Any and How Do They Change?, „Norface Migration Discussion Paper", No 23, http://www.norface-migration.org/publ_uploads/NDP_23_13.pdf [Accessed: 10.09.2017].

Duda-Dziewierz K. (1938), Wieś małopolska a emigracja amerykańska. Studium wsi Babica powiatu rzeszowskiego, Warszawa - Poznań: Polski Instytut Socjologiczny.

Eade J., Drinkwater S., Garapich M. P. (2007), Class and Ethnicity - Polish Migrants in London, http:// www.surrey.ac.uk/cronem/files/POLISH_FINAL_RESEARCH_REPORT_WEB.pdf [Accessed: 23.12.2016].

Fomina J. (2009), Światy równoległe - wizerunek własny Polaków w Wielkiej Brytanii, Warszawa: ISP, http://www.isp.org.pl/files/1975607530144791001254742838.pdf. [data dostępu: 12.10.2017].

Frankfort-Nachmias C., Nachmias D. (2001), Metody badawcze w naukach społecznych, Poznań: Wydawnictwo Zysk i S-ka.

Frelak J., Roguska M., Powroty do Polski. Wyniki badań, Warszawa: ISP. Galasińska A., Kozłowska O. (2009), Discourses of a „Normal Life” among Post-accession Migrants from Poland to Britain, w: Burrell K. (red.), Polish Migration to the UK in the 'New'European Union After 2004, Farnham: Ashgate, s. 87-106.

Garapich M. P. (2008), Odyssean Refugees, Migrants and Power - Construction of 'Other' within the Polish 'Community' in the UK, w: Reed-Danahay D., Brettel C. (red.), Immigration and Citizenship in Europe and the U.S. Anthropological Perspectives, Rutgers, http://www.surrey.ac.uk/ cronem/files/Odyssean_Reffuges_Migrants_and_Power.pdf [Accessed: 10.11.2013].

Garapich M. P. (2010), Chłopi i żołnierze, budowlańcy i pijacy. Dominujący dyskurs migracyjny, jego kontestacje i konsekwencje dla konstruowania polskiej grupy etnicznej w wielokulturowym Lon- 
dynie, w: Grzymała-Moszczyńska H., Kwiatkowska A., Roszak J. (red.), Drogi i rozdroża. Migracje Polaków w Unii Europejskiej. Analiza psychologiczno-socjologiczna, Kraków: Nomos, s. 35-54.

Garstka E. (2015), Sacrum jako aspekt kultury świątecznej - tożsamość młodych Polaków za granica, „Uniwersyteckie Czasopismo Socjologiczne”, nr 13(4), s. 139-147.

Giddens A. (2001), Nowoczesność i tożsamość, 'Ja' i społeczeństwo w epoce późnej nowoczesności, Warszawa: Wydawnictwo Naukowe PWN.

Grabowska-Lusińska I., Okólski M. (2009), Emigracja ostatnia, Warszawa: Wydawnictwo Naukowe SCHOLAR.

Irek M., Małek A., Napierała P., Praszałowicz D., Pustułka P., Pyłat J., Grzymała-Moszczyńska H. (2012), Polskie szkolnictwo w Wielkiej Brytanii: tradycja i nowoczesność - raport, http://pau. krakow.pl/projekty_badawcze/raporty/Polskie_szkolnictwo_UK/Polskie_szkolnictwo_UK_RAPORT.pdf [data dostępu: 17.05.2016].

Jaczewska B. (2014), Polityka integracyjna imigrantów na poziomie lokalnym na przykładzie wybranych miast w Niemczech i Wielkiej Brytanii, „Studia Migracyjne - Przegląd Polonijny”, nr 2, s. 151-176.

Janeta M. (2012), Polacy w Wielkiej Brytanii - emigracja powojenna i poakcesyjna. Różnice, podobieństwa, wzajemne relacje, „Studia Migracyjne - Przegląd Polonijny”, nr 3, s. 5-26.

Jaźwińska E. (2000), Metody ilościowe w badaniach nad migracjami międzynarodowymi, „CMR Working Papers", nr 36.

Kłoskowska A. (1983), Socjologia kultury, Warszawa: PWN.

Krotofil J. (2013), Religia w procesie kształtowania tożsamości wśród polskich migrantów w Wielkiej Brytanii, Kraków: NOMOS.

Lacroix T. (2011), The Indian and Polish Transnational Organisational Fields, „IMI Working Paper", No 40, https://hal.archives-ouvertes.fr/halshs-00820308/document [Accessed: 17.08.2017].

Lisak M. (2010), Religijność i moralne orientacje polskich imigrantów: raport z badań w Dublinie (2008-2010), w: Grubka M., Lisak M. (red.), Polscy migranci w Irlandii: wokót środowiska duszpasterstwa polonijnego. Szkice teologiczne i społeczne, Kraków - Dublin: Esprit-Euro Nexus, s. $135-160$.

Łukowski W. (2001), Społeczny sens ruchliwości niepełnej (biwalentnej), w: Jaźwińska E., Okólski M. (red.), Ludzie na huśtawce. Migracje między peryferiami Polski a Zachodu, Warszawa: Wydawnictwo Naukowe SCHOLAR, s. 125-163.

Metykova M. (2010), Only a Mouse Click Away from Home: Transnational Practices of Eastern European Migrants in the United Kingdom, „Social Identities”, Vol. 16, Issue 3, s. 325-338.

Milewski M., Ruszczak-Żbikowska J. (2008), Motywacje do wyjazdu, praca, więzi społeczne i plany na przyszłość polskich migrantów przebywających w Wielkiej Brytanii i Irlandii, „CMR Working Papers", nr 35/93.

Mostwin D. (1985), Trzecia wartość. Formowanie się nowej tożsamości polskiego emigranta w Ameryce, Lublin: RW KUL.

Mucha J. (1996), Codzienność i odświętność. Polonia w South Bend, Warszawa: Oficyna Naukowa.

Nowicka E. (2010), Migracje powrotne: powrót do domu czy nowa migracja?, w: Grzymała-Moszczyńska H., Kwiatkowska A., Roszak J. (red.), Drogi i rozdroża. Migracje Polaków w Unii Europejskiej. Analiza psychologiczno-socjologiczna, Kraków: Nomos, s. 190-206.

Okólski M. (2001), Mobilność międzynarodowa ludności Polski w okresie transformacji. Przegląd problematyki, w: Jaźwińska E., Okólski M. (red.), Ludzie na huśtawce. Migracje między peryferiami Polski i Zachodu, Warszawa: Wydawnictwo Naukowe SCHOLAR, s. 9-30.

Osipowicz D. (2002), Rola sieci i kapitału społecznego w migracjach zarobkowych. Przykład Moniek, „Prace Migracyjne”, nr 46. 
Paleczny T. (2008), Socjologia tożsamości, Kraków: Krakowskie Towarzystwo Edukacyjne - Oficyna Wydawnicza AFM.

Piętka E. (2011), Encountering Forms of Co-Ethnic Relations Among Polish Community in Glasgow, „Studia Migracyjne - Przegląd Polonijny”, nr 1, s. 129-152.

Rabikowska M. (2010), The ritualisation of food, home and national identity among Polish migrants in London, „Social Identities”, Vol. 16, Issue 3, s. 377-398.

Rabikowska M., Burrell, K. (2009) The material worlds of recent Polish migrants: transnationalism, food, shops and home, w: Burrell K. (red.), Polish migration to the UK in the 'new' European Union, Ashgate: Farnham, s. 211-232.Ravenstein E. G. (1885), The Laws of Migration, „Journal of the Statistical Society of London", Vol. 48, No. 2, s. 167-235.

Slany K., Ślusarczyk M. (2010), Zostać czy wracać? Dylematy emigranta, w: Grzymała-Moszczyńska H., Kwiatkowska A., Roszak J. (red.), Drogi i rozdroża. Migracje Polaków w Unii Europejskiej. Analiza psychologiczno-socjologiczna, Kraków: Nomos, s. 163-177.

Sztabiński P. B., Sztabiński F. (1997), Przywiązanie do miejsca zamieszkania jako wymiar polskiego tradycjonalizmu, w: Domański H., Rychard A. (red.), Elementy nowego ładu, Warszawa: IFiS PAN, s. 256-269.

Sztumski J. (1995), Wstęp do metod i technik badań społecznych, Katowice: Wydawnictwo Śląsk.

Thomas W. I., Znaniecki F. (1976), Chłop polski w Europie i Ameryce. Pamiętnik imigranta, t. III, Warszawa: LSW.

Trevena P., McGhee D., Heath S. (2016), Parental capital and strategies for school choicemaking: Polish parents in England and Scotland, „Central and Eastern European Migration Review, Vol. 4, http://ceemr.uw.edu.pl/articles/parental-capital-and-strategies-school-choicemakingpolish-parents-england-and-scotland, [Accessed: 11.07.2017].

Tuan Y. F. (1987), Przestrzeń i miejsce, Warszawa: PIW. 